\title{
Nature and possible functions of interferons secreted by the preimplantation pig blastocyst
}

\author{
Claude La Bonnardière \\ Unité de Virologie et d'Immunologie Moléculaires, INRA, Jouy en Josas, France
}

In several ungulate species, the preimplantation trophoblast, among various secretions, produces large amounts of antiviral activity that was identified as interferon (IFN). IFNs (types I and II) are pleiotropic cytokines, which in addition to a potent antiviral activity, exert multiple effects on cell growth and differentiation, in particular on the cells of the immune system. In ruminants, trophoblastic IFN, or trophoblast protein-1 (TP-1), was found to consist of a multigenic family related to type I IFN- $\omega$. These IFNs exert hormone-like effects through receptors present on the endometrium, leading to the prolongation of luteal lifespan and hence to sustained progesterone secretion. In pigs, a species in which the maternal recognition of pregnancy is controlled by conceptus-derived oestrogens, two IFNs have been found in the preimplantation trophoblast. The major species is IFN- $\gamma$ (type II), that so far had been found only in activated T lymphocytes and natural killer (NK) cells. Transcription of the IFN- $\gamma$ gene in the pig trophoblast differs from that in mature lymphocytes, since two mRNAs are present. The other component with antiviral activity is a novel type I IFN; distant in sequence from IFN- $\alpha, \beta, \omega$, and containing seven cysteines in its deduced mature protein. These two unrelated IFNs are temporally co-induced, with maximal secretion at day 16 of pregnancy. Specific receptors for both IFNs have been found on endometrial epithelial cells, but not on the preimplantation trophoblast, suggesting a paracrine effect on the uterus. Different hypotheses as to their role(s) in the establishment or maintenance of implantation are discussed. Whereas an indirect anti-infectious (antiviral) protection of the conceptus by IFNs cannot be ruled out, arguments are presented that do not favour a role in the immune tolerance of the conceptus.

\section{Introduction}

It has become well established that conceptuses from several ungulate species, before and at the time of implantation, secrete proteins that belong to the interferon families (Imakawa et al., 1987). Simmen and Simmen (1990) briefly reviewed data obtained in ruminants. Since that time, a great deal of work has been done and published in sheep and cattle, giving a more precise view on the structure and function(s) of ruminant trophoblastin protein-1 (TP-1) (see below). Trophoblastic interferons have also been found and identified in pigs.

This paper will review most of the comprehensive literature on embryonic interferons in farm animals, their source, molecular structure and role(s), whenever possible, paying particular attention to pigs, which as yet represent a unique species as far as the nature and possible role of embryonic interferons are concerned. For the sake of clarity, some basic properties of the two components of this secretion, namely the trophoblast and the interferons will be briefly reviewed. 
Functions

Apical plasma membrane

- regulation of nutrient and water uptake

- regulated secretion (pathway A)

- protection

Lateral plasma membrane

- cell contact and adhesion

- cell communication

\section{Components}

Apical plasma membrane

- Hydrolases

- Amiloride-sensitive $\mathrm{Ne}^{+}$channel

- $\mathrm{Na}^{+}$-dependent transporters

- $\mathrm{Cl}^{-}$channel

- $\mathrm{H}^{+}$-ATPase

- Proteins linked via glycosyl-phosphatidylinositol

- Glycolipids

Lateral plasma membrane

- Cell adhesion molecules

- Junctional complex: Zonula occludens (ZO) Zonula adherens (ZA) Desmosomes (D) Gap junctions (GJ)

Basal-lateral membrane - signal reception and transduction

- generation of ion gradients

- constitutive secretion (pathway B)

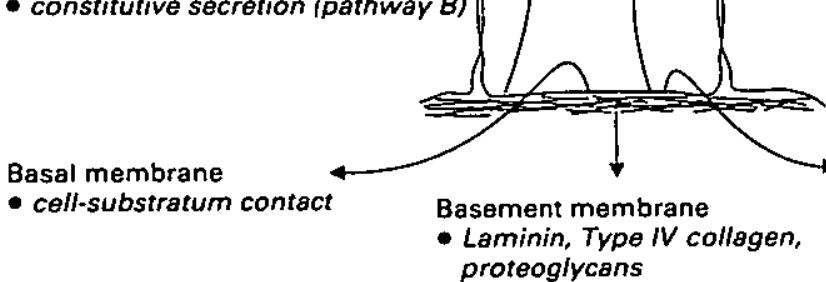

Basal-lateral membrane

- Anion channel $\left(\mathrm{Cl}^{-}-\mathrm{HCO}_{3}{ }^{-}\right.$exchanger

- $\mathrm{Na}^{+}, \mathrm{K}^{+}$-ATPase

- Growth factor receptors

- Hormone and neurotransmitter receptors

- Transduction systems associated with receptors

Basal membrane

- Basement membrane receptors

Fig. 1. The polarized epithelial phenotype: functionally and biochemically distinct plasma membrane domains. The apical domain of the plasma membrane faces the lumen and carries out uptake of ions and nutrients from this biological compartment via specific ion channels and transporters. In secretory epithelial cells, the apical plasma membrane is usually the site of regulated secretion (pathway A). The lateral membrane is the site of cell-cell contact and communication, which are mediated by specialized components of the junctional complex. Tight junctions (zonula occludens, $\mathrm{ZO}$ ) block the paracellular pathway between lumen and serosa and form a diffusion barrier in the plane of the lipid bilayer. Cell-cell communication is mediated by gap junctions (GJ). specialized intercellular channels for small solutes. The basal plasma membrane is attached to the basement membrane (basal lamina) through specific receptors for laminin, type IV collagen and proteoglycans. Enzymes, transport activities and receptors localized to the basal-lateral plasma membrane are involved in the generation of ion gradients across the apical plasma membrane in signal reception and transduction, and in the constitutive secretion (pathway B). (Reproduced from RodriguezBoulan and Nelson, with permission).

\section{Functional Properties of the Trophoblast}

\section{A polarized cell}

The formation of trophectoderm is the first overt sign of differentiation in early embryonic development. One of the most important morphological features to appear in the outer cells of the early compacting embryo is the presence of intercellular junctional complexes (Enders, 1971; Rodriguez-Boulan and Nelson, 1989). This permeability barrier initially plays an essential role in the establishment of a distinct microenvironment within the embryo, so that the blastocoelic fluid can initially accumulate in the interstices between the cells, and then induce the blastocyst expansion (Kaufman, 1983). Thus, the trophoblast is a typical polarized epithelial cell, capable of a variety of functions reflected by a polarized distribution of enzymes and transport systems to specific domains of the plasma membrane. A generic model of this phenotype, as proposed by Rodriguez-Boulan and Nelson, is shown (Fig. 1). A capacity to actively transport water and solutes is well illustrated in trophoblastic vesicles, spheroids that form and swell up from freshly fragmented trophoblast (Fig. 2). Only trophoblastic vesicles with two cell layers (endoderm plus trophectoderm) swell up and secrete IFN into the surrounding medium. In ruminants, trophectoderm vesicles have been used successfully as vectors in vivo of conceptus secretory proteins (Heyman et al, 1982). In pigs, they constitute useful tools for ultrastructural studies (Whyte et al., 1986), 


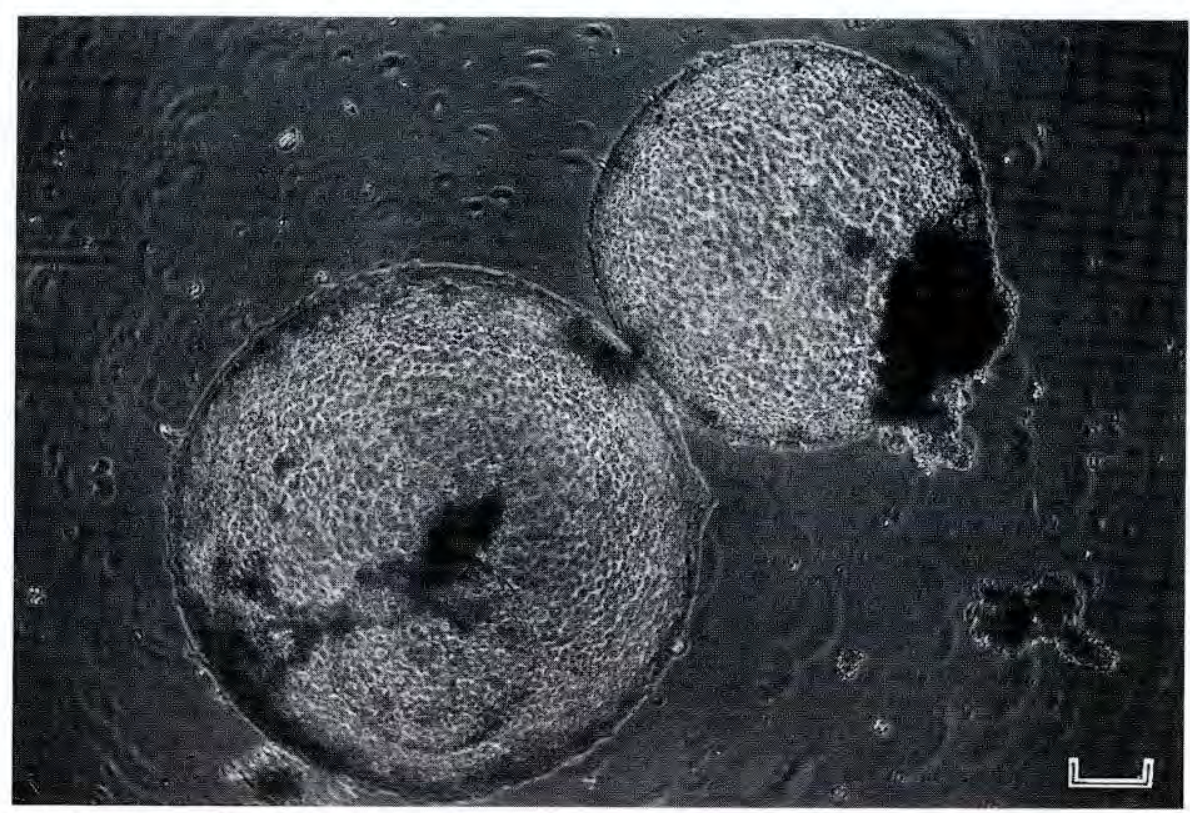

Fig. 2. Trophoblastic vesicles obtained from a day-14 pig conceptus (phase contrast microscopy). Scale bar $=50 \mu \mathrm{m}$.

studies on glucose metabolism (Selgrath et al. 1989), and assay of the trophectoderm susceptibility to viral infection (D'Andrea et al., 1992). The vectorial transport performed by the trophectoderm has obvious implications for the regulation of the interface of the embryo with its environment. In addition, the trophoblast expresses membrane receptors, synthesizes and secretes steroid hormones and proteins (see below) that participate in the metabolic, endocrinological and possibly immunological functions required for the establishment and maintenance of pregnancy. The possible coupling between secretory and vectorial transport are under study in some epithelial cell lines, but, with respect to the trophoblast, normal, nontransformed cell lines will have to be established as tools for a better understanding of this multifunctional cell.

\section{The regulation of implantation}

Among the large number of proteins secreted by the preimplantation pig trophoblast (Godkin et al., 1982), a few have been identified. One of them is plasminogen activator (PA), a proteolytic enzyme that is secreted by many invasive cell types, including mouse trophoblast cells. The finding of PA in the noninvasive pig trophoblast occurred simultaneously with the finding of a uterine, progesterone-induced PA inhibitor, the production of which coincides with that of PA (Mullins et al., 1980). This proteaseinhibitor interaction between uterus and conceptus might be one mechanism by which the uterus resists the otherwise potentially invasive trophoblast (reviewed by Strickland and Richards, 1992).

\section{Cytokine cross-talk}

In the two best studied species, characterized by haemochorial placentation, it is well established that a complex exchange of cytokines takes place between the two cell layers forming the placenta. In humans, the syncytiotrophoblast or cytotrophoblast produces a number of growth factors, for example granulocyte-macrophage colony stimulating factor (GM-CSF), colony-stimulating factor (CSF), transforming growth factor alpha (TGF- $\alpha$ ), fibroblast growth factor (FGF) and insulin-like growth factor II (IGF-II), and in addition some lymphokines, for example interleukin 2 and 6 (IL-2, IL-6), for which cellular receptors are expressed by maternal cells (see Boehm et al., 1989 and Bellet, 1992 for reviews). The endometrial cells are also active in the synthesis and secretion of various cytokines into the uterine lumen. 
Table 1. Main characteristics of interferons (human)

\begin{tabular}{|c|c|c|c|c|c|c|}
\hline Type & $\begin{array}{c}\text { IFN } \\
\text { species }\end{array}$ & $\begin{array}{l}\text { Gene structure } \\
\text { (chromosome) }\end{array}$ & $\begin{array}{l}\text { Known } \\
\text { inducers }\end{array}$ & $\begin{array}{l}\text { Producing } \\
\text { cell }\end{array}$ & $\begin{array}{c}\text { Size of } \\
\text { mature protein } \\
\text { (amino acids) }\end{array}$ & $\begin{array}{l}\text { Specific } \\
\text { cell } \\
\text { receptor }^{\mathrm{a}}\end{array}$ \\
\hline \multirow[t]{3}{*}{ I } & IFN- $\alpha$ & $\begin{array}{l}>20 \text { intronless loci } \\
\text { (4 pseudogenes) } \\
\quad(\text { chr } 9)\end{array}$ & $\begin{array}{l}\text { Viruses } \\
\text { Infected cells } \\
\text { Bacterial components }\end{array}$ & $\begin{array}{l}\text { Leucocytes } \\
\text { Macrophages }\end{array}$ & $165-166$ & I \\
\hline & IFN- $\beta$ & $\begin{array}{l}1 \text { intronless locus } \\
\text { (chr 9) }\end{array}$ & $\begin{array}{l}\text { Viruses } \\
\text { DS RNA }\end{array}$ & Fibroblasts & 166 & I \\
\hline & IFN- $\omega^{b}$ & $\begin{array}{l}\geqslant 7 \text { intronless loci } \\
\text { (6 pseudogenes) } \\
\quad(\mathrm{chr} 9)\end{array}$ & $\begin{array}{l}\text { Viruses } \\
\text { (other ?) }\end{array}$ & $\begin{array}{l}\text { Leucocytes } \\
\text { (others?) }\end{array}$ & 172 & I \\
\hline II & IFN- $\gamma$ & $\begin{array}{l}\text { I locus with } 3 \text { introns } \\
\text { (chr } 12 \text { ) }\end{array}$ & $\begin{array}{l}\text { Antigens } \\
\text { Mitogens }\end{array}$ & $\begin{array}{l}\text { T lymphocytes } \\
\text { Large granular } \\
\text { lymphocytes }\end{array}$ & 143 & II \\
\hline
\end{tabular}

${ }^{a}$ Numbers I and II designate specific receptors for types I and II IFNs, respectively.

'IFNs found in early pregnancy in ruminants (IFN- $\tau$ ) belong to a species closely related to IFN- $\omega$. The human counterpart has not been described so far.

In mice for example, GM-CSF and CSF-1, glycoproteins known to promote the proliferation and differentiation of mononuclear phagocytic cells, are secreted by glandular epithelial cells into the uterine lumen (Pollard et al., 1987; Robertson and Seamark, 1991). Corresponding receptors (for example for CSF-1: the product of the proto-oncogene c-fms) are expressed on the trophoblast (Sherr et al., 1983). The hypothesis that CSF-I might promote the growth and invasiveness of the trophoblasts, is not consistent with the finding of c-fms expression by non-invasive bovine trophoblast (Beauchamp and Croy, 1991). If this receptor is functional, another function must therefore be postulated.

One of the most clear-cut effects of a cytokine in pregnancy is the leukaemia inhibitory factor (LIF), a pleiotrophic cytokine produced by many different tissues (for a review see Kurzrock et al., 1991). In particular, LIF is produced, under maternal control, by mouse uterine glandular cells on day 4 of pregnancy, that is at the onset of implantation (Bhatt et al., 1991). Mice homozygous for a disrupted LIF gene by homologous recombination were used to demonstrate that there is an absolute requirement of maternal LIF expression for blastocyst implantation (Stewart et al., 1992). In this regard, it is interesting that pig endometrium secretes LIF just before the onset of implantation (I. Anegon, personal communication).

Apart from interferons (see below), few cytokines have yet been identified in the pig trophoblast. RT-PCR performed on preimplantation conceptus mRNA detected very small amounts of IL- 6 , but the presence of the protein was not examined (Mathialagan et al., 1992). This brief overview shows that the two epithelia involved at the maternal-embryonic interface are fully capable of cytokine cross-talk, which suggests an important role of these growth factors and regulatory cytokines in the initial stages of implantation.

\section{Major Functions of Interferons}

Originally discovered by virologists (Isaac and Lindenmann, 1957), interferons (IFN) are proteins or glycoproteins that are produced in response to viruses (IFNs $\alpha, \beta$ and $\omega$ ) and in the course of an immune response, in particular to bacterial and parasitic infections (IFN- $\gamma$ ). A brief description of the four main IFN species and some of their molecular and biological characteristics are shown (Table 1). IFNs interact with specific membrane receptors on most cells of the organism, leading to up- and downregulation of 
Table 2. Some of the genes/functions regulated by interferon-gamma

\begin{tabular}{|c|c|c|c|}
\hline Function & Genes/proteins & $\begin{array}{l}\text { Induction/ } \\
\text { regulation }\end{array}$ & Cells \\
\hline Antiviral & $\begin{array}{l}2-5 \mathrm{~A} \text { synthetase } \\
\text { Protein kinase } \\
\text { Mx } 1 \text { gene }\end{array}$ & $\begin{array}{l}\text { Ind } \\
\text { Ind } \\
\text { Ind }\end{array}$ & $\begin{array}{l}\text { Most cells } \\
\text { Most cells } \\
\text { Most cells }\end{array}$ \\
\hline Specific immunity & $\begin{array}{l}\text { MHC class II } \\
\text { MHC class I (incl. } \beta_{2} M \text { ) } \\
\text { Fc receptors } \\
\text { Ig switch }\end{array}$ & $\begin{array}{l}\text { Ind } \\
\text { Up } \\
\text { Up } \\
\text { Ind }\end{array}$ & $\begin{array}{l}\text { Many tissues } \\
\text { Most cells } \\
\text { Macrophages, lymphocytes } \\
\text { B lymphocytes }\end{array}$ \\
\hline Nonspecific immunity & $\begin{array}{l}\text { IL-1, CSF } \\
\text { IL-4 } \\
\text { TNF } \\
\text { Complement } \mathrm{C}_{3} \text { b-receptor }\end{array}$ & $\begin{array}{l}\text { Up } \\
\text { Down } \\
\text { Up } \\
\text { Down }\end{array}$ & $\begin{array}{l}\text { Macrophages + others } \\
\text { T lymphocytes } \\
\text { Macrophages + others } \\
\text { Macrophages }\end{array}$ \\
\hline Adhesion/metrix & $\begin{array}{l}\text { ICAM-1 } \\
\text { Collagen } \\
\text { Fibronectin }\end{array}$ & $\begin{array}{l}\text { Up } \\
\text { Down } \\
\text { Up }\end{array}$ & $\begin{array}{l}\text { Endothelia, fibroblasts } \\
\text { Fibroblasts } \\
\text { Macrophages }\end{array}$ \\
\hline Cell growth/differentiation & $\begin{array}{l}\text { (MHC class II) } \\
\text { c-myc } \\
\text { EGF receptors }\end{array}$ & $\begin{array}{l}\text { Up or down } \\
\text { Down }\end{array}$ & $\begin{array}{l}\text { Many cells } \\
\text { Epithelia }\end{array}$ \\
\hline
\end{tabular}

MHC: major histocompatibility complex; $\beta_{2} \mathrm{M}: \beta_{2}$-microglobulin; IL-1: interleukin 1; IL-4: interleukin 4; TNF: tumour necrosis factor; ICAM-1: intercellular adhesion molecule 1; EGF: epidermal growth factor.

numerous cell functions. A general property of all IFNs is the induction, in sensitive cells, of a transient resistance to a broad range of viruses. This effect is extremely efficient since very few (perhaps a single) IFN molecules per cell suffice to induce the antiviral state. Endogenously produced IFNs have been recognized as an efficient first line of defence against viral diseases (Gresser et al., 1976). But, in addition, IFNs are now recognized as multipotent cytokines, as they have been found to be involved in the modulations of the immune response to pathogens, and have various other functions related to cell growth and differentiation. They present antitumor activity in humans and animals (for review see De Maeyer and De Maeyer-Guignard, 1988).

Whereas various type I IFNs share sequence homology, are encoded by clustered genes (chromosome 9 in humans) and bind to a common receptor chain (Uzé et al., 1990), IFN- $\gamma$ (or type II) is distinct according to most criteria: its gene is split (three introns), is localized on a different chromosome ( 12 in humans: chr. 12) and binds to a distinct receptor (De Maeyer and De Maeyer-Guignard, 1992). Paradoxically, IFN- $\gamma$ displays all known properties of type I IFNs including antiviral activity, and in addition exerts specific effects on the cellular immune response. The best way to characterize IFN- $\gamma$ is as a powerful macrophage activating factor, and some of the genes/functions presented (Table 2) relate to this property. The macrophage, a pivotal cell in the immune system, is relatively rich in IFN- $\gamma$ receptors (De Maeyer and De Maeyer-Guignard, 1988). IFN- $\gamma$, which as yet has only been recognized in T lymphocytes and natural killer cells, is a lymphokine, induced in the process of lymphocyte activation by antigens and mitogens. It is important to mention this trait in view of the recently described secretion of IFN- $\gamma$ by the pig trophoblast (see below).

What precedes constitutes a 'historical' perspective of discoveries concerning IFNs, which were logically viewed as anti-infectious and anti-tumoural cytokines. It is now clear that the role of these molecules should be reconsidered in the light of more recent developments in the field of physiology. The brief review that follows on IFNs and pregnancy will stress the importance of the two types (I and II) of IFNs, the expression of which is developmentally regulated, and which certainly play a crucial role in implantation, maintenance of pregnancy or both processes. Can we adhere to the assumption made by 
T. Chard "If the knowledge accumulated in the past 4 years on the reproductive role of interferon .... had been available 20 years ago, ... this molecule would have been designated as a reproductive hormone"? (Chard, 1991)

\section{Hormone-like Effect of Trophoblast IFNs in Ruminants}

Since 1987, when it was first reported that the cDNA sequence of ovine trophoblast proteins (oTP-1, or trophoblastin) was related to a type I IFN (Imakawa et al., 1987), evidence has accumulated that confirmed and extended this finding (Stewart et al., 1987; Charpigny et al., 1988; Stewart et al., 1989; Charlier et al., 1989; Imakawa et al., 1989). oTP-1 and bovine bTP-1 proteins were found more related to IFN- $\omega$ (previous name: IFN- $\alpha$ II), with 172 amino acids in total length and $70 \%$ sequence similarity with known bovine and human IFN- $\omega$ (Charlier et al., 1989; Hansen et al., 1991). More recently the goat conceptus has also been shown to produce an abundant caprine TP-1 protein (cTP-1) (Baumbach et al., 1990). There is no doubt that these trophoblast IFNs, now proposed as IFN- $\tau$ to distinguish them from IFN- $\omega$, belong to a multigenic family (Hansen et al., 1991), the exact size of which is unknown. As confirmation, five different isoforms of oTP-I were secreted by the same ovine conceptus (Martal et al., 1988). It is possible that co-induction of several isoforms constitutes an efficient means of dosage amplification.

The interferon nature of oTP-1 was confirmed by its antiviral activity (Pontzer et al., 1988; Klemann et al., 1990), antiproliferative effect on human and bovine cells (Pontzer et al., 1991), binding to the same cell receptor as IFNs- $\alpha,-\beta$ and $-\omega$ (Stewart et al., 1987; Flores et al., 1991) and stimulation in susceptible cells of $2^{\prime}-5^{\prime}$ oligo-A synthetase (Short et al., 1991).

The question of tissue-specific expression of these IFN- $\tau$ was relevant, since there is no report of TP1 -like IFN in any other physiological or pathological process. Transfection experiments using IFN- $\tau$ genes or constructs using IFN- $\tau$ promoter have shown that only trophoblast-derived cell lines (e.g. JAR choriocarcinoma line) can express these IFNs in the absence of viral induction (Cross and Roberts, 1991). RNA transcripts for bTP-1 have been found by RT-PCR in conceptuses obtained by in vitro maturation and in vitro fertilization as early as the differentiation of the trophectoderm, suggesting that bTP-I gene regulation is genetically programmed (Hernandez-Ledezma et al., 1992).

High-affinity binding sites for OTP-I are present in endometrial membranes (Godkin et al., 1984), and data have accumulated showing that oTP-1 (bTP-1) or IFN- $\tau$ exerts an anti-luteolytic effect allowing a sustained progesterone supply by the corpus luteum in pregnant ewes (for reviews see Niswender and Nett, 1988; Bazer and Johnson, 1991; Roberts et al., 1992). Although it is well accepted that oTP-1 (or type I IFNs) suppresses oxytocin-mediated pulsatile prostaglandin synthesis (which occurs in cyclic females), the exact mechanism of IFN- $\tau$ /oTP-1 action is still controversial (see Jenkin, 1992). It is not our purpose to delve into the details of this topic, but we will stress that IFN- $\tau$ clearly plays an important role in ruminants in the maternal recognition of pregnancy, most probably via an interaction with endometrial receptors. As far as we know, no significant detection of IFN activity has ever been reported in the serum of pregnant dams, suggesting a complete confinement of IFN- $\tau$ to the luminal compartment of the uterus. This is not incompatible with the fact that administration of recombinant bovine IFN- $\alpha 1$ by general route (i.m.) to cyclic cows extends luteal lifespan in treated animals (Plante et al., 1989, 1991), provided IFN receptors are also present on the basolateral membrane of the endometrial epithelium.

\section{IFNs Secreted by the Pig Conceptus}

\section{The hormonal context}

Although it shares some common anatomical and physiological features with ruminants in regard to early pregnancy, the pig presents particularities in the endocrine interplay leading to recognition of pregnancy (Bazer et al., 1989). In pregnant sows, two phenomena have been described: (1) inhibition of the endometrial synthesis of $\mathrm{PGF}_{2 \alpha}$ and (2) increase of the luminal concentration of $\mathrm{PGF}_{2 \alpha}$ (Moeljono et al., 1977; Schille et al., 1979; Zavy et al., 1980; Guthrie and Rexroad, 1981). Treatment with oestrogens 
between days 11 and 15 after oestrus maintains luteal lifespan in nonpregnant sows for up to 300 days (Gardner et al., 1963; Frank et al., 1977). In addition, the porcine conceptus secretes oestrogens from day 11 (Perry et al., 1973; Gadsby et al., 1980). These data and others provide the basis for a model whereby conceptus-derived oestrogens prevent luteolytic $\mathrm{PGF}_{2 \alpha}$ from reaching corpora lutea by the double effect of inhibition of its synthesis and reversal of the direction of its secretion (Bazer and Thatcher, 1977).

According to this hypothesis, no anti-luteolytic proteins equivalent to trophoblastin are suspected in the pig. Infusion of total conceptus secretory proteins in the uterus of cyclic sows did not prolong luteal lifespan, which supports the above model (Harney and Bazer, 1989).

\section{Origin of antiviral activity of the pig conceptus}

A significant antiviral activity was found in uterine flushings and in conceptus-conditioned culture medium on days 11-17 of pregnancy (Cross and Roberts, 1989). Electrophoresis and immunoblotting of conceptus secreted proteins revealed several bands that were recognized by an antiserum to human IFN- $\alpha$, but not by antibodies to ovine TP-I (IFN- $\tau$ ). IFN secretion by the pig conceptus was confirmed, beginning on days 12-13 of pregnancy, and reached a maximum titre on days 15-16 (Mirando et al., 1990). Unexpectedly, these authors detected low antiviral activity in the uterine artery and uterine vein in all gilts including cyclic ones, suggesting that this activity is not produced by the conceptus (a result later confirmed by Short et al., 1991). Additions of fragments of endometrium to in vitro conceptus cultures decreased the secretion of antiviral activity, suggesting that the uterus might regulate its synthesis or secretion (Beers et al., 1990).

\section{Identification of two interferons}

Further analysis of this antiviral activity by seroneutralization was performed by our group, using various antisera, one of which was a rabbit serum towards recombinant porcine IFN- $\gamma$ (Charley et al., 1988). This reveals that at least two species of IFN are present in uterine flushings and in supernatants of conceptus-conditioned media (Lefèvre et al., 1990; La Bonnardière et al., 1991). One is interferon-gamma, the predominant species, the other is a type I IFN, at first suspected to be IFN- $\alpha$ since it is neutralized by antibodies to human leucocyte IFN (type I). The addition of antisera corresponding to both IFNs is required to neutralize most of the antiviral activity, but 3-5\% residual activity resists inactivation.

Interferon-gamma. IFN- $\gamma$ synthesis and secretion by the implanting conceptus has been confirmed by several methods (Lefèvre et al., 1990): First of all, immunoprecipitation of conceptus secreted proteins by antiserum to rPoIFN- $\gamma$ yields four bands in SDS-acrylamide gel electrophoresis (SDS-PAGE), with apparent molecular masses of $18.5,20.5,23$ and $24.5 \mathrm{kDa}$. These four protein species resolve into a single band of $16.5 \mathrm{kDa}$ upon pretreatment with glycopeptidase $\mathrm{F}$, which is reminiscent of the various glycosylated forms of natural human IFN- $\gamma$ (Langer and Petska, 1985). Second, northern blot analysis of days $14-17$ conceptus mRNAs reveals two bands of 1.3 and $1.4 \mathrm{~kb}$ that hybridize with an IFN- $\gamma$ probe (Fig. 3). Finally, use of an immunofluorescence test, using a rabbit antiserum to porcine IFN- $\gamma$ and FITCconjugated anti-rabbit IgG antibodies performed on thin sections of conceptuses showed that all cells of the extraembryonic trophectoderm intensively secrete IFN- $\gamma$ on their apical pole (Fig. 4). This unexpected result constituted the first report of IFN- $\gamma$ in a tissue with no relation to the haematopoietic lineage. The specific transcriptional regulation of IFN- $\gamma$ in the trophoblast (activated T lymphocytes express only one mRNA) is not yet understood, but it has been demonstrated that both mRNAs are transcribed from the same unique gene for IFN- $\gamma$ (Lefèvre et al., 1992) and give rise by in vitro translation to a single (unglycosylated) IFN- $\gamma$ polypeptide (Lefèvre et al., 1990). It can be postulated that this specific regulation might constitute an efficient means of amplification of IFN- $\gamma$ synthesis. By analogy with human and mouse IFN- $\gamma$, the native form of PoIFN- $\gamma$ is most probably a dimer of about $45 \mathrm{kDa}$ (De Maeyer and De Maeyer-Guignard, 1988) that resolves into monomers upon SDS-PAGE. In this regard, the group of basic proteins in the range of $35-50 \mathrm{kDa}$ that was previously analysed in two-dimensional, denaturing PAGE as major products of pig conceptus from day 13 are unlikely to represent or include IFN- $\gamma$ (Godkin et al., 1982). 


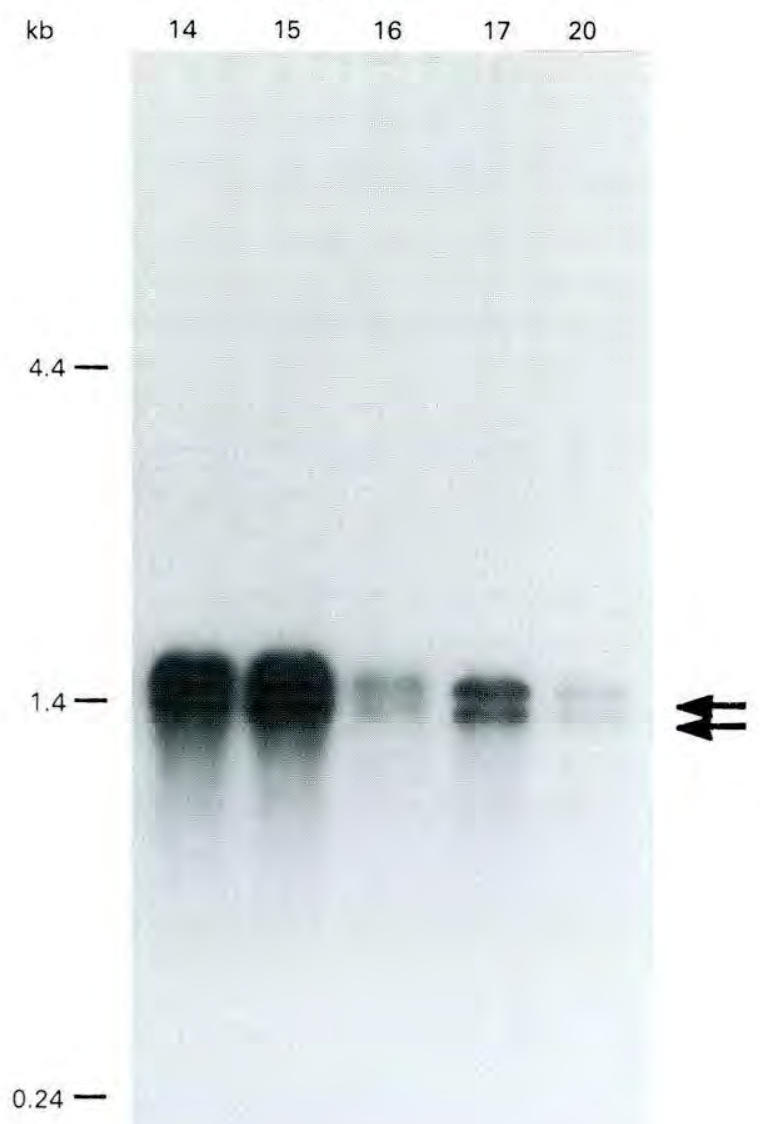

Fig. 3. Identification of mRNA cross-hybridizing to human IFN- $\gamma$ cDNA in porcine conceptuses during the implantation period. Poly $(\mathrm{A})^{+} \mathrm{mRNAs}$ from conceptus tissues were analysed by northern blot and hybridized with a human IFN- $\gamma$ cDNA probe under low stringency. The two RNA transcripts detected ( 1.3 and $1.4 \mathrm{~kb})$ are indicated by arrows.

Porcine embryonic type I interferon. By analogy with ruminant conceptuses, we expected that pig type I IFN could be IFN- $\omega$-like. This hypothesis was tested by several methods using previously cloned porcine IFN- $\omega$ cDNAs, and the result was negative (Mège et al., 1991). However, a cDNA library constructed from day 14-15 conceptuses was shown to contain, in addition to abundant IFN- $\gamma$ clones (about $2 \%$ ), less frequent clones that hybridized weakly to a pig IFN- $\omega$ cDNA probe $(0.01-0.02 \%$ of total clones). Among these, one cDNA encoding a functional IFN was isolated. Its sequence revealed a novel type I IFN gene, distantly related to the IFN $-\alpha,-\beta$ and $-\omega$ sequences $(27-42 \%$ homology). Its deduced amino acid sequence revealed a 170 amino acid long preprotein, and a putative signal peptide of 21 residues. The mature protein, with 149 residues, and a basic isoelectric point, would then represent the shortest type I IFN known, and also the richest in cysteine (seven residues). The provisional name spI IFN (for short porcine type I) is proposed (Lefèvre and Boulay, 1993).

The gene encoding this spI IFN was cloned from a pig genomic library, showing that, like other type I IFNs it is devoid of introns. The upsteam DNA regulatory sequence presents no homology with those of other type I IFNs, and in particular it does not contain canonical virus-inducible elements. In addition, 


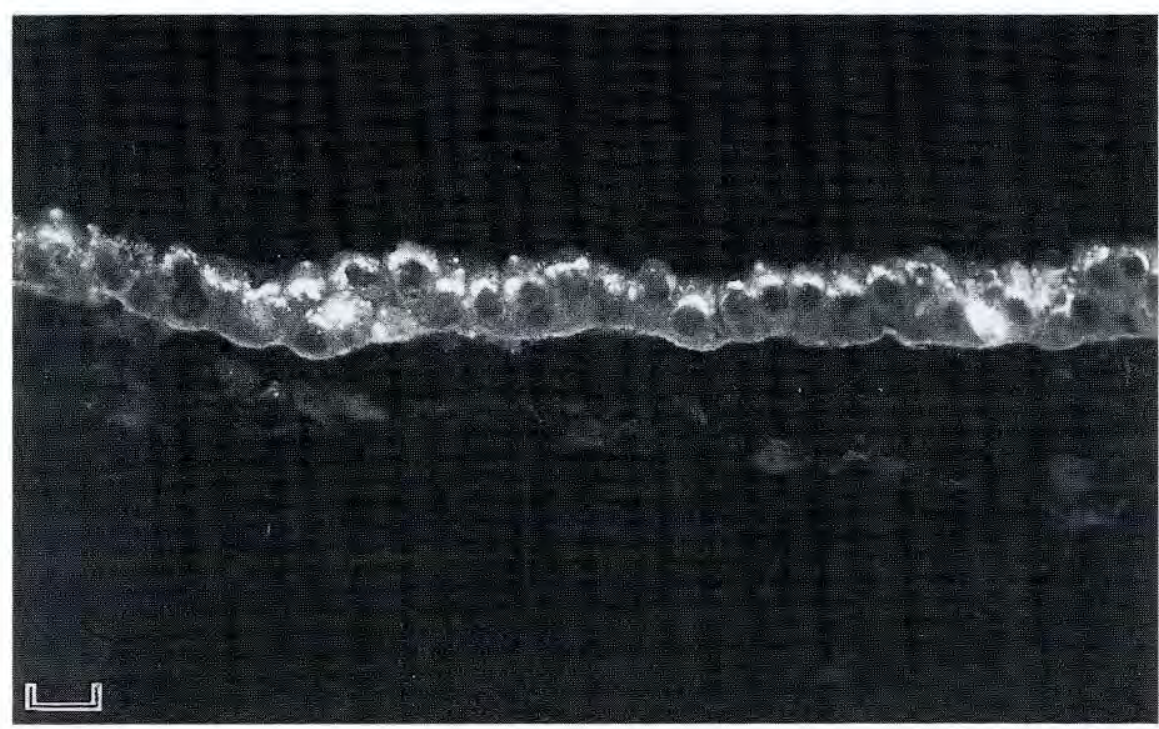

Fig. 4. Detection of immunoreactive IFN- $\gamma$ on thin sections of the trophectoderm of a day-16 pig conceptus using a rabbit antiserum to porcine IFN- $\gamma$. The first antibody was rabbit antiserum to recombinant porcine IFN- $\gamma$ (dilution 1:100). Second reagent was FITC-conjugated sheep anti-rabbit IgG antibodies (dilution 1:400). The fluorescence is located only in the apical cytoplasm of trophectoderm cells and absent from the endoderm layer. Scale bar $=20 \mu \mathrm{m}$.

it possesses three $30-40 \mathrm{bp}$ long repeats, each containing a core GC-rich sequence homologous to consensus binding sites for transcription factor AP-2. It is probable that a new family of type I IFNs has thus been defined (Lefèvre et al., 1992).

Analysis by northern blots of spI mRNA in the conceptus indicates that the kinetics of its expression parallels that of IFN- $\gamma$. In addition, it has been confirmed that the eukaryotic expression of spI cDNA results in a protein, with high specific antiviral activity, that is almost completely neutralized by an antiserum to human leucocyte IFN, just as is the activity found with IFN- $\gamma$ in uterine flushings.

The pig trophectoderm therefore simultaneously expresses and secretes both type I and II IFNs, which appear to be developmentally regulated. The recent development of porcine trophoblast cell lines that synthesize and secrete IFN- $\gamma$ suggests that maternal signal(s) for induction of expression (La Bonnardière $\mathrm{et} \mathrm{al}$., this symposium are not required). The co-expression of type I and II IFNs suggests: (1) a unique tissue-specific regulation of IFN genes; (2) a possible synergistic effect on the target tissue(s), since synergy between IFN- $\gamma$ and type I IFNs in in vitro culture systems is well documented (De Maeyer and De Maeyer-Guignard, 1992).

\section{The role of pig conceptus IFNs}

The role(s) of pig conceptus IFNs is at present only speculative. IFNs are only one of the multiple secretions of the trophoblast around implantation, and we are far from understanding the specific role(s) of each of these, their possible cascade inductions, and their possible interconnections. In the light of relevant published data, this review intends to present some realistic hypotheses as to the possible roles of the pig embryonic IFNs.

Absence of autocrine effect. The first question to address is whether IFN- $\gamma$ (and spI IFN) secretion is autocrine, or in other words: does the implanting trophoblast have functional IFN receptors? Experiments have shown that this is not the case. Trophoblastic vesicles maintained in vitro are extremely sensitive to viral infection, even when pretreated with high doses of IFN (type I or II). In addition, fresh conceptus tissue cannot specifically bind to IFN- $\gamma$, nor is it inducible by IFN- $\gamma$ or spI IFN for the enzyme $2^{\prime}-5^{\prime}$ oligo-A synthetase taken as a marker (D'Andrea et al., 1992). This was expected because of the known 
antiproliferative effects of IFNs, as most IFN activity is secreted during the elongation stage of the blastocyst. The possibility of a differentiating effect on the embryo itself remains, but relevant data are not available.

The uterine epithelium is a possible target of conceptus IFNs, and it has been shown that functional receptors are present on its cells (D'Andrea et al., 1992). If the uterine epithelium is indeed the target, several kinds of effects can be considered.

Antiviral activity. An antiviral role must not be ruled out, and would result in total prevention of endometrial virus production. Indeed it has been shown that the blastocyst is quite susceptible to virus infection, in the mouse as well as in the pig (Zusman et al., 1984; D'Andrea et al., 1992). The endometrium at the time of implantation is hypervascularized (Leiser and Dantzer, 1988), which might increase the risk of infection by viraemic particles. If so, the conceptus would sustain via the uterus its own protection against lethal virus infection, without the undesirable autocrine effects. In mice, in which no significant IFN activity is detected at implantation, a constitutive expression of MxI gene was found in the epithelial lining of the uterus (and duodenum), independent of blood-borne IFN (Chang et al., 1990), probably raising a barrier to influenza infections.

Hormonal effect. A hormonal effect is also possible, alone or in conjunction with conceptus-derived oestrogens, that would contribute to the maintenance of corpora lutea, or to uterine receptivity. One possibility is that IFNs might participate as a redundant effector to the oestrogen-induced inhibition or redirection of secretion $\mathrm{PGF}_{2 \alpha}$. It is possible that in previous infusion experiments performed on cyclic sows with total conceptus secretory proteins (Harney and Bazer, 1989), the amount of IFN was suboptimal compared with that produced in utero by the conceptus.

\section{A regulatory role in immunity?}

It has been clearly demonstrated in humans and mice that the preimplantation trophoblast does not express classical transplantation antigens (see Koch, 1985 for review). In humans, the MHC class I HLA-A and -B antigens are not expressed, although their mRNAs are weakly transcribed, and class II HLA-D protein is absent. Only extravillous trophoblast expresses a non-classical MHC class I antigen, HLA-G (reviewed by Hunt, 1992). This G chain is monomorphic (Kovats et al., 1990), and therefore may not be viewed as an alloantigen by the maternal immune system. An equivalent to the HLA-G determinant has been found in the rat trophoblast (Kanbour-Shakir et al., 1990). There is some evidence that this monomorphic class I antigen is responsible for trophoblast resistance to lysis by decidual lymphocytes analogous to natural killer cells (NK), or large granular lymphocytes (LGL) (Kovats et al., 1991). An overview of presently available data and models on MHC antigens and pregnancy in humans and rodents could be tentatively summarized as follows: the null or reduced expression of 'classical' polymorphic MHC proteins allows the trophoblast to escape killing by maternal MHC-restricted, alloreactive T lymphocytes; in the meantime, the expression of monomorphic MHC class I chain (for example human HLA-G) would prevent lysis and hence rejection by endometrial NK/LGL cells (reviewed by King and Loke, 1991).

To what extent could these data help in understanding the role played by IFN- $\gamma$ in pigs? Although IFN- $\gamma$ is a potent activator of MHC antigens on many cell types (De Maeyer and De Maeyer-Guignard, 1988), the effects of IFN- $\gamma$ on trophoblast MHC expression is complex, and should be regarded with caution since most experiments in humans and rodents have been performed using trophoblastic or embryo-derived cell lines. For example, IFN- $\gamma$ can restore the surface expression of classical H2-D antigen in mouse embryo-derived cell lines (Bikoff et al., 1991), whereas it has no inducer activity on human trophoblast cells that do not express HLA-G (reviewed by Hunt and Orr, 1992).

Concerning pig MHC antigens (SLA), $\beta 2$-microglobulin was expressed at the apex of trophectoderm cells between days 6 and 12 (Meziou et al., 1983), suggesting that MHC class I antigens are expressed, but the alpha chain complement has not been identified. However, the finding that the pig preimplantation trophoblast has no functional IFN receptors almost rules out a modulation by IFN- $\gamma$ of MHC antigens, whatever they are. Concerning the endometrial side, cells with NK activity are recruited and activated in the uterus of pregnant sows (Croy et al., 1988). Trophoblast IFN- $\gamma$ could therefore be an 
activator of such cells, but do embryonic IFNs reach the endometrial stroma and how can the paradox of the stimulation of the maternal cytotoxic effects by the conceptus be explained?

However, the classical mechanisms of transplantation biology do not seem to be involved in the maternal response to implantation (see King and Loke, 1991). Moreover, the work by the group of B. A. Croy showing that scid./scid. bg/bg mice, which are deficient in B, T and NK cells are nomally fertile and fecund (Croy and Chapeau, 1990), casts a serious doubt on models whereby the maternal immune response to paternally derived antigens on the conceptus would play a major role in successful pregnancy.

This caution should a fortiore apply to species with epitheliochorial placentation like pigs, in which there is neither invasive trophoblast, nor uterine decidualization.

\section{Conclusion}

Much work remains to be done before the role(s) played by cytokines, particularly IFNs, in implantation can be understood. Clearly, in ruminants, IFN- $\tau / \mathrm{TP}-1$ proteins are antiluteolysins. But is it relevant to address the question of another possible role, that would be common to (at least) ruminants and Suidae. First, there is a very close time coincidence of IFN secretion in sheep and pigs. Second, both species have developed specific trophoblastic expression of IFN with sophisticated means of amplification of secretion (different isoforms in the sheep, two mRNA for IFN- $\gamma$ in the pig) or activity (possible synergy between types I and II IFN in the pig). This argues for a strong requirement for the presence of highly active IFNs at the exact period of implantation. If one admits that JFNs are not antiluteolysins in pigs, then the understanding of the role(s) played by trophoblastic IFNs in this species could probably be valid in sheep and cows. We want to stress here that IFNs are defensive molecules against infections, and this must be considered when discussing their possible effects at the uterus-conceptus interface.

A comparison of species like ruminants and pigs with mice is very difficult since so many parameters related to early pregnancy differ, among which are the delay between hatching and implantation, and the type of placentation. In any case, no consistent antiviral activity was found in mice at the implantation period, and this is unfortunate as the mouse is the only species in which evaluation of specific functions by inactivation of the corresponding genes is possible. Concerning domestic species, experiments could be carried out to neutralize in vivo the activity of IFNs, using antibodies to either the cytokine or its receptor.

\section{References}

Baumbach GA, Duby RT and Godkin JD (1990) N-glycosylated and unglycosylated forms of caprine trophoblast protein 1 are secreted by preimplantation goat concephuses Biochemical Biophysical Research Communications 172 16-20

Bazer FW and Johnson HM (1991) Type I conceptus interferons: matemal recognition of pregnancy signals and potential therapeutic agents American Joumal of Reproductive Immunology 26 19-22

Bazer FW and Thatcher WW (1977) Theory of maternal recognition in swine based on estrogen controlled endocrine versus exocrine secretion of prostaglandin $F_{20}$ by uterine endometrium Prosiaglandins 14 397-401

Bazer FW, Vallet JL, Gross TS and Thatcher WW (1989) Comparative aspects of maternal recognition of pregnancy between sheep and pigs Joumal of Reproduction and Fertility Supplement 37 85-89

Beauchamp JL and Croy BA (1991) Assessment of expression of the receptor for colony-stimulating factor-1 (fms) in bovine trophoblast Biology of Reproduction $45811-817$

Beers S, Mirando MA, Pontzer CH, Harney JP, Torres BA, Johnson HM and Bazer FW (1990) Influence of the endo- metrium, protease inhibitors and freezing on antiviral activity of proteins secreted by pig conceptuses Jourmal of Reproduction and Fertility 88 205-211

Bellet D (1992) Biologie du tissu trophoblastique et des tumeurs placentaires Revue du Praticien 4281 I-816

Bhatt H. Brunet LJ and Stewart CL (1991) Uterine expression of leukemia inhibitory factor coincides with the onset of blastocyst implantation Proceedings of the National Academy of Sciences USA 88 11408-11412

Bikoff E, Jaffe L, Ribaudo RK, Otten GR, Gemain RN and Robertson EJ (1991) MHC class I expression in embryoderived cell lines inducible with peptide or interferon Nature 354 235-238

Boehm KD, Kelley MP, Jlan JO and Ju I (1989) The interleukin 2 gene is expressed in the syncytiotrophoblast of the human placenta Proceedings of the National Academy of Sciences USA 86 656-660

Chang KC, Gerlach C, Femandes K, Lida J and Goldspink G (1990) The influenza resistance murine $\mathrm{Mxl}$ gene is constitutively expressed in the epithelia of the gastrointestinal, respiratory and uterine tracts Jounal of Cell Science 97 497-502 
Chard T (1991) Interferon- $\alpha$ is a reproductive hormone fountal of Endocrinology 131 337-338

Charley B, McCullough K and Martinod S (1988) Antiviral and antigenic properties of recombinant porcine interferon gamma Veterinary Immunology and Immunopathology 19 95-103

Charlier M, Hue D. Martal J and Gaye P (1989) Cloning and expression of CDNA encoding ovine trophoblastin: its identity with a class II alpha interferon Gente 77 341-348

Charpigny G, Reinaud P, Hue D, Guillomot M, Charlier $M$, Pernollet JC and Martal J (1988) High homology between a trophoblastic protein (trophoblastin) isolated from ovine embryo and $\alpha$-interferons FEBS Letiers 228 12-16

Cross JC and Roberts RM (1989) Porcine conceptuses secrete an interferon during the preattachment period of early pregnancy Biology of Reproduction 40 1109-1118

Cross JC and Roberts RM (1991) Constitutive and trophoblastspecific expression of a class of bovine interferon genes Proceedings of the National Academy of Scientes, USA 88 3817-3821

Croy BA and Chapeau C (1990) Evaluation of the pregnancy immunotrophism hypothesis by assessment of the reproductive performance of young adult mice of genotype scid/scid bg/bg joumal of Reproduction and Fertility 88 231-239

Croy BA, Waterfield A, Wood W and King G (1988) Normal murine and porcine embryos recruit NK cells to the uterus Celludar Immonology 115 471-480

D'Andréa S, Choustermann S, Lefèvre F and La Bonnardière C (1992) Paracrine activity of porcine trophoblastic interferons on endometrial cells Joumal of interferon Research 12 (Supplement 1) S185

De Maeyer E and De Maeyer-Guignard J (1988) Interferon and Other Regulatory Cytokines. Wyleg. New York

De Maeyer E and De Maeyer-Guignard J (1992) Interferon- $\gamma$ Current Opinion in Immunology 4 321-326

Enders AC (1971) The fine structure of the blastocyst: some comparative studies. In Biology of the Blastocyst, pp 71-94 Ed. RJ Blandeau. University of Chicago Press, Chicago

Flores I, Mariano TM and Petska S (1991) Human interferon omega $(\omega)$ binds to the $\alpha / \beta$ receptor joumal of Biological Chemistry 266 19875-19877

Frank M, Bazer FW. Thatcher WW and Wilcox CJ (1977) A study of prostaglandin $\mathrm{F} 2 \alpha$ as the luteolysin in gilts. III Effects of estradiol valerate on prostaglandin $F$, progestin, estrone and estradiol concentrations in the utero-ovarian veins of nonpregnant gilts Prostaglandins 14 1183-1196

Gadsby JE, Heap RB and Burton RD (1980) Oestrogen production by blastocyst and early embryonic tissue of various species Joumal of Reproduction and Fertility $60409-417$

Gardner ML, First NL and Casida LE (1963) Effect of exogenous estrogens on corpus luteum maintenance in gilts joumal of Animal Science 14 470-474

Godkin JD, Bazer FW, Lewis GS, Geisert RD and Roberts RM (1982) Synthesis and release of polypeptides by pig conceptuses during the period of blastocyst elongation and attachment Biology of Reproduction 27 977-987

Godkin JD, Bazer FW and Roberts RM (1984) Ovine trophoblast protein 1, an early secreted blastocyst protein, binds specifically to uterine endometrium and affects protein synthesis Endocrinology 114 120-130

Gresser I, Tovey MG, Bandu MT, Maury C and Brouty-Boyé D (1976) Role of interferon in the pathogenesis of virus disease as demonstrated by the use of anti-interferon sera 1. Rapid evolution of encephalomyocarditis virus infection Joumal of Experimental Medicine 144 1305-1315

Guthrie HD and Rexroad CE (1981) Endometrial prostaglandin $F$ release in vitro and plasma 13,14-dihydro-15-ketoprostaglandin $\mathrm{F} 2 \alpha$ in pigs with luteolysis blocked by pregnancy, estradiol benzoate or human chorionic gonadotropin Jounal of Animal Science 52 330-339

Hansen TR, Leaman DW, Cross JC, Mathialagan N, Bixby JA and Roberts RM (1991) The genes for the trophoblast interferons and the related interferon- $u$ II possess distinct 5 '-promoter and 3'-flanking sequences Jourtal of Biological Chemistry 266 3060-3067

Harney JP and Bazer FW (1989) Effect of porcine conceptus secretory proteins on interestrous interval and uterine secretion of prostaglandins Biology of Reproduction $\mathbf{4 1}$ 277-284

Hemandez-Ledezma JJ. Sikes JD, Murphy CN, Watson AJ, Schultz GA and Roberts RM (1992) Expression of bovine trophoblast interferon in conceptuses derived by in vitro techniques Biology of Reproduction 47 374-380

Heyman Y, Camous S, Fèvre J, Meziou W and Martal J (1982) Maintenance of the corpus luteum after uterine transfer of trophoblastic vesicles to cyclic cows and sheep joumal of Reproduction and Fertilify 70 533-540

Hunt JS (1992) Immunobiology of pregnancy Current Opinion in inmunology 4 591-596

Hunt JS and Orr HT (1992) HLA and matemal-fetal recognition FASEB Joumal 6 2344-2348

Imakawa K, Anthony RV, Kazemi M, Marotti KR, Polites HC and Roberts RM (1987) Interferon-like sequence of ovine trophoblast protein secreted by embryonic trophectoderm Nature $330377-379$

Imakawa K, Hansen TR, Malathy PV, Anthony RV, Polites HG, Marotti KR and Roberts RM (1989) Molecular cloning and characterisation of CDNAs corresponding to bTP-1; a comparison with oTP-1 and bovine IFN-all Molecular Endocrinology 3 127-139

Isaac $A$ and Lindenmann J (1957) Virus interference $I:$ the interferon Proceedings of the Royal Society (B) 147258

Jenkin $\mathrm{C}$ (1992) Interaction between oxytocin and prostaglandin F2a during luteal regression and early pregnancy in sheep Reproduction Fertility and Developnent 4 329-334

Kanbour-Shakir A, Zhang X, Rouleau A, Armstrong DT, Kunz HW, MacPherson TA and Gill TJ (1990) Gene imprinting and major histocompatibility complex class I antigen expression in the rat placenta Proceedings of the National Academy of Sciences, USA 87 444-448

Kaufman MH (1983) The origin, properties and fate of trophoblast in the mouse. In Biology of Trophoblast, pp 21-63 Eds YW Loke and A Whyte. Elsevier, Amsterdam

King $A$ and Loke YW (1991) On the nature and function of human granular lymphocytes Immunology Today 12 $432-435$

Klemann SW, Li J, Imakawa K, Cross JC, Francies $H$ and Roberts RM (1990) The production, purification and bioactivity of bovine trophoblast protein-1 (bovine trophoblast interferon) Molecular Endocrinology 4 1506-1514

Koch E (1985) Establishment of pregnancy and its immunological implications in the pig Joumal of Reproduction and Fertility Supplement 33 65-81

Kovats S, Main EK, Librach C, Stubblebine M, Fisher SJ and De Mars R (1990) A class I antigen, HLA-G, expressed in human trophoblasts Science 248 220-223

Kovats S, Librach C, Fish P, Main EK, Sondel PM, Fisher S] and De Mars R (1991) Expression and possible function of the 
HLA-G alpha chain in human cytotrophoblasts. In Cellular and Molecular Biology of the Materno-fetal Relationship, PP 21-28 Eds G Chaouat and J Mowbray. Colloques INSERM, Paris

Kurzrock R, Estrov Z, Wetzler M, Gutterman JU and Talpaz M (1991) LIF: not just a leukemia inhibitory factor Endocrine Reviews 12 208-217

La Bonnardière C, Martinat-Botte F, Terqui M, Lefèvre F, Zouari K, Martal J and Bazer FW (1991) Production of two species of interferons by Large White and Meishan pig conceptuses during the peri-attachment period Jourtal of Reproduction and Fertility 91 469-478

Langer JA and Petska $S$ (1985) Structure of interferons Phamacology and Themapeutics 27 371-401

Lefèvre F, Martinat-Botte F, Guillomot M, Zouari K, Charley $B$ and La Bonnardière C (1990) Interferon-gamma gene and protein are spontaneously expressed by the porcine trophectoderm early in gestation European Journal of lmmunology 20 2485-2490

Lefèvre F, Boulay $V$ and la Bonnardière C (1992) IFN- $\psi$ : a new type one embryonic IFN expressed during early pregnancy Jounual of Interferon Research 12 (Supplement 1) S186

Lefèvre $F$ and Boulay $V$ (1993) A novel and atypical type one interferon gene expressed by trophoblast during early pregnancy joumal of Biological Chemistry (in press)

Leiser $R$ and Dantzer V (1988) Structural and functional aspects of porcine placental microvasculature Anatomy and Embryology 177 409-419

Martal J, Charpigny C, Reinaud P. Huet JC, Guillomot M, Zonari K, Pernollet JC and La Bonnardière C (1988) joumal of Reproduction and Ferility Abstracts Series 2 Abstract 3

Mathialagan N, Bixby JA and Roberts RM (1992) Expression of interleukin- 6 in porcine, ovine and bovine preimplantation conceptuses Molecular Reproduction and Development 32 324-330

Mège D, Lefèvre F and La Bonnardière $C$ (1991) The porcine family of interferon-(1): cloning, structural analysis and functional studies of five related genes joumal of Inierferon Research 11 341-350

Meziou W, Chardon P. Flechon JE, Kalil J and Valman M (1983) Expression of $\beta_{2}$-microglobulin on preimplantation pig embryos Joumal of Reproductive Immunology 5 73-78

Mirando MA, Harney JP, Beers S, Pontzer CH. Torres BA, Johnson HM and Bazer FW (1990) Onset of secretion of proteins with antiviral activity by pig conceptuses Joumal of Reproduction and Fertility 88 197-203

Moeljono MPE, Thatcher WW, Bazer FW, Frank M, Owens LJ and Wilson CJ (1977) Study of prostaglandin F2a as the luteolysin in swine: 11 Characterization and comparison of prostaglandin $\mathrm{F}$, estrogens and progestin concentrations in utero-ovarian vein plasma of nonpregnant and pregnant gilts Prostaglandins 14 543-555

Mullins DE. Bazer FW and Roberts RM (1980) Secretion of a progesterone-induced inhibitor of plasminogen activator by the porcine uterus Cell $20865-872$

Niswender GD and Nett T (1988) The corpus luteum and its control. In The Physiology of Reproduction, Pp 489-525 Eds E Knobil and JD Neill. Raven Press, New York

Perry JS, Heap RB and Amoroso EC (1973) Steroid hormone production by pig blastocysts Nature 245 45-47

Plante C, Hansen PJ, Martinod S and Siegenthaler B (1989) Effect of intrauterine and intramuscular administration of recombi. nant bovine interferon $\alpha 1$ on luteal lifespan in cattle foumal of Dairy Science 72 1859-1865
Plante C. Thatcher WW and Hansen PJ (1991) Alterations of oestrous cycle length, ovarian function and oxytocin-induced release of prostaglandin F-2 $\alpha$ by intrauterine and intramuscular administration of recombinant bovine interferon- $\alpha$ to cows Jounal of Reproduction and Fertility 93 375-384

Pollard JW, Bartocci A, Arceci R, Orlofsky A, Ladner MB and Stanley ER (1987) Apparent role of the macrophage growth factor, CSF-1, in placental development Nahure 330 484-486

Pontzer CH, Torres BA, Valtet JL, Bazer FW and Johnson HM (1988) Antiviral activity of the pregnancy recognition hormone ovine trophoblast protein 1 Biochemical and Biophysical Research Conmunicalions 152 801-807

Pontzer CH, Bazer FW and Johnson HM (1991) Antiproliferative activity of a pregnancy recognition hormone, ovine trophoblast protein I Cancer Research 51 5304-5307

Roberts RM, Cross JC and Leaman DW (1992) Interferons as hormones of pregnancy Endocrine Reviews 13 432-452

Robertson SA and Seamark RF (1991) Uterine granulocytemacrophage colony stimulating factors in early preg. nancy: cellular origin and potential regulators. In Cellular and Molecular Biology of the Materto-fetal Relationship. pp 113-121 Eds G. Chaouat and J. Mowbray. Colloques INSERM/John Libbey, Paris

Rodriguez-Boulan E and Nelson WJ (1989) Morphogenesis of the polarized epithelial cell phenotype Science 245 718-725

Schille WM, Karlbom I, Einarsson S, Larson K, Kindahl $H$ and Edqvist LE (1979) Concentrations of progesterone and 15-keto-13,14-dihydro-prostaglandin $\mathrm{F} 2 \alpha$ in peripheral plasma during the estrous cycle and early pregnancy in gilts Zentralblatt Veterinarmedizinische Reihe A26 169-181

Selgrath JP, Flood MR and Wright RW (1989) Clucose utilisation by enzymatically-formed trophoblastic vesicles and day-14 porcine blastocysts Theriogenology 32 37-43

Sherr CJ, Rettenmeier CW, Sacca R, Roussel MF, Look AT and Stanley ER (1983) The cfms proto-oncogène product is related to the receptor for the mononuclear phagocyte growth factor. CSFI Cell $41665-675$

Short EC, Geisert RD, Helmer SD, Zavy MT and Fulton RW (1991) Expression of antiviral activity and induction of $\mathbf{2}^{\prime} \cdot \mathbf{5}^{\prime}$ oligoadenylate synthetase by conceptus secretory proteins enriched in bovine trophoblast protein-1 Biology of Reproduction 44 261-268

Simmen RCM and Simmen FA (1990) Regulation of uterine and conceptus secretory activity in the pig Jountal of Reproduction and Fertility Supplement 40 279-292

Stewart CL, Kaspar P, Brunet LJ, Bhatt H, Gadi I, Köntgen F and Abbondanzo J (1992) Blastocyst implantation depends on maternal expression of leukemia inhibitory factor Nature $35976-79$

Stewart HJ, MacCann SH, Barker PJ, Lee KE, Lamming GE and Flint APF (1987) Interferon sequence homology and receptor binding activity of ovine trophoblast antiluteolytic protein Joumal of Endocrinology 115 R 13-R15

Stewart H), MacCann SHE, Northrop AJ, Lamming GE and Flint APF (1989) Sheep antiluteolytic interferon: cDNA sequence and analysis of mRNA levels joumal of Molecular Endocrinology 2 65-70

Strickland S and Richards WC (1992) Invasion of the trophoblasts Cell 71 355-357

Uzé G, Lutfalla G and Gresser I (1990) Genetic transfer of a functional human interferon a receptor into mouse cells: cloning and expression of its cDNA Cell 60 225-234 
Whyte A, Wooding FBP and Sanders PTK (1986) Characteristics of cellular structures derived by tissue culture of preimplantation blastocysts of the pig Archives d'Anatomie et de Cytologie Pathologiques 75 91-109.

Zavy MT, Bazer FW, Thatcher WW and Wilcox C] (1980) A study of prostaglandin $\mathrm{F} 2 \alpha$ as the luteolysin in swine: $V$ Comparison of prostaglandin F, progestins, estrone and estradiol in uterine flushings from pregnant and nonpregnant gilts Prostaglandins 20 837-85I

Zusman I, Engelhard D, Yaffe P. Ron A, Panet A and Ornay A (1984) Effects of interferon and encephalomyocarditis virus on in vitro development of preimplantation mouse embryos with and without the zona pellucida Teratology 29 405-409 